\title{
An approach on food choice determinants: a study in the restaurants of a public market in Northeastern Brazil
}

\section{Abordagem sobre determinantes de escolha alimentar: um estudo nos restaurantes de um mercado público do Nordeste do Brasil}

Ana Claudia Carvalho MOURA' ID 0000-0002-9930-8552

Martha Teresa Siqueira Marques MELO' ${ }^{1}$ 0000-0002-5858-9298

Bianca Lourrany dos Santos SILVA ${ }^{1}$ (ID) 0000-0001-9432-5268

Suzana Maria Rebêlo Sampaio da PAZ1 ID 0000-0002-4236-0771

Adriana de Azevedo PAIVA ${ }^{1}$ (ID) 0000-0002-6009-3793

Cecilia Maria Resende Gonçalves de CARVALHO1 ID) 0000-0002-8707-1447

\section{A B S T R A C T}

\section{Objective}

To identify the main determinants of food consumption among adult users of a public market in a capital of Northeastern Brazil.

\section{Methods}

A total of 198 diners in a public market, constituting a sample comprising 149 males and 49 females over 19 years of age, was interviewed using a pre-tested questionnaires from August 2018 to January 2019. Sociodemographic variables such as gender, age, place of origin, education and income, in addition to the determinants of food choices were evaluated. The analysis was performed using the Wilcoxon test (nonparametric) that compared the means of the dimensions involved in these choices according to gender and income.

\footnotetext{
1 Universidade Federal do Piauí, Departamento de Nutrição, Programa de Pós-Graduação em Alimentos e Nutrição. Campus Ministro Petrônio Portella, bloco 13, 64049-550, Teresina, PI, Brasil. Correspondente to: A.C.C. MOURA. E-mail: <anaclaudiacarvalho@ufpi.edu.br>.

Article elaborated from dissertation by A.C.C. MOURA, entitled "O Mercado Público de Teresina: a lógica das escolhas alimentares determinantes no comportamento do consumidor do Mercado da Piçarra”. Universidade Federal do Piauí; 2019.

\section{How to cite this article}

Moura ACC, Melo MTSM, Silva BLS, Paz SMRS, Paiva AA, Carvalho CMRG. An approach on food choice determinants: a study in the restaurants of a public market in Northeastern Brazil. Rev Nutr. 2020;33:e190126. https://doi. org/10.1590/1678-9865202033e190126
} 


\section{Results}

Sensory appeal, price and health were the main determinants of food choices. When compared by gender and income, there were significant differences regarding the attributes reviewed.

\section{Conclusion}

The factors that influenced food choice were: sensory appeal, price and health. Ethical issues were the ones that least interfered with food choice. Thus, such aspects must be taken into account for the development of public policies in the area of collective eating and environmental education. The factors that influenced food choice were: sensory appeal, price and health. Ethical issues were the ones that least interfered with food choice. Thus, such aspects must be taken into account for the development of public policies in the area of collective eating and environmental education.

Keywords: Collective feeding. Feeding. Feeding behavior.

\section{RE S U M O}

\section{Objetivo}

Identificar os principais determinantes do consumo alimentar entre adultos usuários de um mercado público de uma capital do nordeste brasileiro.

\section{Métodos}

Foram entrevistados, por intermédio de questionários pré-testados, nos meses de agosto de 2018 até janeiro de 2019, uma amostra de 198 comensais de um mercado público, constituída por 149 indivíduos do sexo masculino e 49 do sexo feminino maiores de 19 anos. Foram avaliadas variáveis sociodemográficas como sexo, idade, local de origem, escolaridade e renda, além dos determinantes das escolhas alimentares. A análise foi feita utilizando o teste de Wilcoxon (não paramétrico), que comparou as médias das dimensões envolvidas nessas escolhas conforme sexo e renda.

\section{Resultados}

Apelo sensorial, preço e saúde foram os principais determinantes das escolhas alimentares. Quando comparados por sexo e renda, houve diferenças significativas quanto aos atributos analisados.

\section{Conclusão}

Os fatores que influenciaram a escolha alimentar foram: apelo sensorial, preço e saúde. Já as questões éticas foram as que menos interferiram na escolha alimentar. Desse modo, tais aspectos devem ser levados em consideração para o desenvolvimento de políticas públicas na área de alimentação coletiva e educação ambiental.

Palavras-chave: Alimentação coletiva. Alimentação. Comportamento alimentar.

\section{INTRODUCTION}

The intense economic, demographic and social changes that occurred with the globalization process led to changes in dietary patterns, levels of physical activity and health status [1]. Such changes favored the increase in the consumption of food outside the home and affected the quality of the food, with the substitution of traditional foods for processed foods [2].

In this framework, the Family Budget Survey portrays the gradual increase in spending with eating outside the home in the Brazilian population, that increased from $24.1 \%$ in the 2002-2003 biennium to $32.8 \%$ in the $2017-2018$ period [3]. Among the options for eating outside, public markets stand out; they constitute the main foodstuff supply warehouses during the process of cities formation which, over time, incorporated new functions, becoming places of reference in food and cultural identity of a people $[4,5]$.

To assess the impact of food on health, the study of dietary patterns reviewed diet in general, guiding policies to foster healthy eating and prevent nutritional disorders [6]. Thus, the study of these patterns is a relevant aspect to become knowledgeable of the factors involved and that determine the food choice. 
In this connection, the determinants of food consumption are factors that affect the choice of food through individual thoughts and feelings, resulting in actions or behaviors [7]. Food choice concerns conscious and unconscious decisions taken in relation to food, covering physiological, psychological, social, economic and cultural aspects $[8,9]$.

Studies conducted in Brazil, point out that among the determinants of food choice, taste and nutritional aspects, in connection with both health and food composition, are the main factors that influence the process of food choice, with flavor often being pointed out as a key predictor of consumption. The appearance of the food, including color and shape, texture, temperature, fat content and other characteristics present in the food also contribute to the perception of taste and influence food choices more than knowledge of the health benefits of food. The pleasure obtained from eating by the set of sensory characteristics seems to be at the center of the development, maintenance and changes in eating habits $[7,10]$.

The socioeconomic determinants of the individual, such as income, education and food prices, have a strong influence on motivations and food choices, being able to limit, unbalance and interfere in the priorities related to these processes [7]. It is noteworthy that, although the food decision-making moment is individual, food choices are habit forming drivers and have a significant influence on health [11]. Thus, thinking about eating outside the home in a social context that often contributes to inappropriate food choices represents an important study element. Certainly, the act of eating is a practice rich in symbolic meanings and diverse experiences [12]. Furthermore, there is little research that evaluates the relationships among the social contexts of eating and eating patterns in public markets.

Thus, the following questions were raised: what are the factors that motivate the individual in the decision to consume a certain food? Which dimension regarding food choice stands out, the one related to the characteristics of the food or the one related to the individual? Therefore, the aim of this study was to identify the main determinants of food consumption among adult users of a public market in a capital city in Northeastern Brazil.

\section{METHODS}

This cross-sectional, exploratory, descriptive study, linked to a research project of the Graduate Program in Food Nutrition was approved by the Research Ethics Committee of the Universidade Federal do Piauí (opinion No. 2,139,962), after authorization by the Teresina Municipality.

The study was carried out between the months of August 2018 and January 2019 in a public market, located in the center of the city of Teresina, Piauí, chosen because it is considered a cultural-historical heritage, a reference in the area of popular food. The referred market deploys 22 restaurants that produce typical regional foods such as corn and rice couscous, fried cake, panelada, sarapatel, buchada, caipira chicken and lamb in sauce, which are served in individual portions, and the protein preparations can be served with side dishes of rice, beans, pasta and salad.

Participants were recruited at random; those who agreed to participate in the study, signed a Free and Informed Consent Form. The criteria defined for the participation of individuals in the study were: be over 19 years old, both genders and conventionally, those who were having their meal at the market at the time of the interviews, so that it would be possible to know the profile of the public that usually goes to the restaurants of this establishment. In order to observe the functioning of the market, field visits were made on alternate days until all days of the week were covered, including holidays and weekends. 
According to the data provided by the Teresina Municipality in 2016, the market was visited by 600 people daily. Starting from this universe, considering the level of confidence (95\%) and sample error (5\%), the predicted sample of our study was 175 individuals [13].

The survey was conducted with people having breakfast, snacks and lunch during the period of operation of the market's meal sector, during the entire service hours (4:00am to 3:00pm), selected at random; the questionnaire was applied in the interval after the customer had chosen the preparations and the end of the meal, avoiding the inclusion of individuals already interviewed in previous days.

As a data collection instrument, a semi-structured questionnaire was developed that surveyed sociodemographic aspects such as gender, age, place of origin, education and income. This questionnaire was applied by a team of undergraduate and graduate students in the field of nutrition, previously trained by the investigators responsible for standardizing the methods.

To review the determinants of food choice, the Food Choice Questionnaire (FCQ), created by the Englishman Steptoe in 1995 was applied after it was translated, adapted and validated for the Brazilian adult population. With the aim at validating the process, this instrument was first applied to 86 students [14-16].

The central question of the FCQ that the participants had to answer was the level of importance that the food consumed on a daily basis would have. Thus, 36 items were evaluated in this perspective, which were classified by a scoring scale whose degree of importance varied from one to four: one was equivalent to not important, two to slightly important, three to moderately important and four to very important $[15,16]$.

These items covered dimensions related to food (sensory appeal, natural content, price and familiarity) and to the individual (health, mood, convenience, weight control and ethical concern). The convenience dimension included ease in preparing and accessing food; humor was related to mood and well-being; and ethical concern with the environment $[15,16]$.

From the data obtained in the questionnaires, a database was developed, in which the investigated variables were coded, entered into a Microsoft Office Excel spreadsheet and reviewed using the Stata ${ }^{\circledR}$ version 12 statistical package [17].

For the statistical analysis of the study the following was estimated: variables, frequency distributions, means, standard deviations and proportions. The analysis of the determinants of food choice was performed by comparing the averages attributed to each dimension assessed, due to the uniformity of the data. The analysis of the differences in the mean scores for each of the dimensions of the FCQ according to gender and income was performed using the Wilcoxon test (nonparametric). For statistical tests, the level of significance adopted was $p<0.05$.

Although food choice is a complex process that includes several variables, the reasons for the approach by gender and income are justified, as they are social determinants in health [18]. Admittedly, there is a greater social pressure for women to remain within a weight standard considered ideal, which can influence and interfere in their food choices. Economic condition is another factor that can influence consumer attitudes and preferences, therefore, it can limit and determine food choices [19].

\section{RE S U L T S}

A total of 203 participants responded to the survey. Five interviewees dropped out and the study was completed with 198 participants, of which more than half $(75.0 \%)$ were male. The predominant age group was in the range of 30 to 39 years (29.3\%). Most participants lived in the 
city of Teresina (85.0\%) and had up to a higher education level (46.0\%). A total of $48.5 \%$ reported a family income below two minimum wages. The characteristics related to the social and demographic profile are described in Table 1.

Figure 1 shows the average of the study participants' evaluation according to the dimensions assessed by the FCQ, in which we can perceive that the most appreciated attribute varied in the Likert scale from moderately important to very important (3 to 4), with sensory appeal (3.8), price (3.7) and

Table 1. Sociodemographic variables of the interviewed population. Teresina (PI), Brazil, 2019.

\begin{tabular}{|c|c|c|c|}
\hline Characteristics & Category & $n$ & $\%$ \\
\hline \multirow[t]{2}{*}{ Gender } & Male & 149 & 75.0 \\
\hline & Female & 49 & 25.0 \\
\hline \multirow[t]{4}{*}{ Age } & 20 to 29 years & 47 & 23.7 \\
\hline & 30 to 39 years & 58 & 29.3 \\
\hline & 40 to 49 years & 47 & 23.8 \\
\hline & $>50$ years & 46 & 23.2 \\
\hline \multirow[t]{2}{*}{ Place of origin } & Teresina & 168 & 85.0 \\
\hline & Other locations & 30 & 15.0 \\
\hline \multirow[t]{3}{*}{ Education } & Complete Elementary School & 27 & 13.6 \\
\hline & Complete High School & 80 & 40.4 \\
\hline & Complete Higher Education & 91 & 46.0 \\
\hline \multirow[t]{5}{*}{ Income } & Has no income & 10 & 5.0 \\
\hline & Less than $2 \mathrm{MW}^{*}$ & 96 & 48.5 \\
\hline & Between 2 and 5MW & 58 & 29.3 \\
\hline & More than 5MW & 28 & 14.0 \\
\hline & Did not answer & 06 & 3.0 \\
\hline
\end{tabular}

Note: *The Minimum wage at the time of the interview was R\$954.00 (reais).

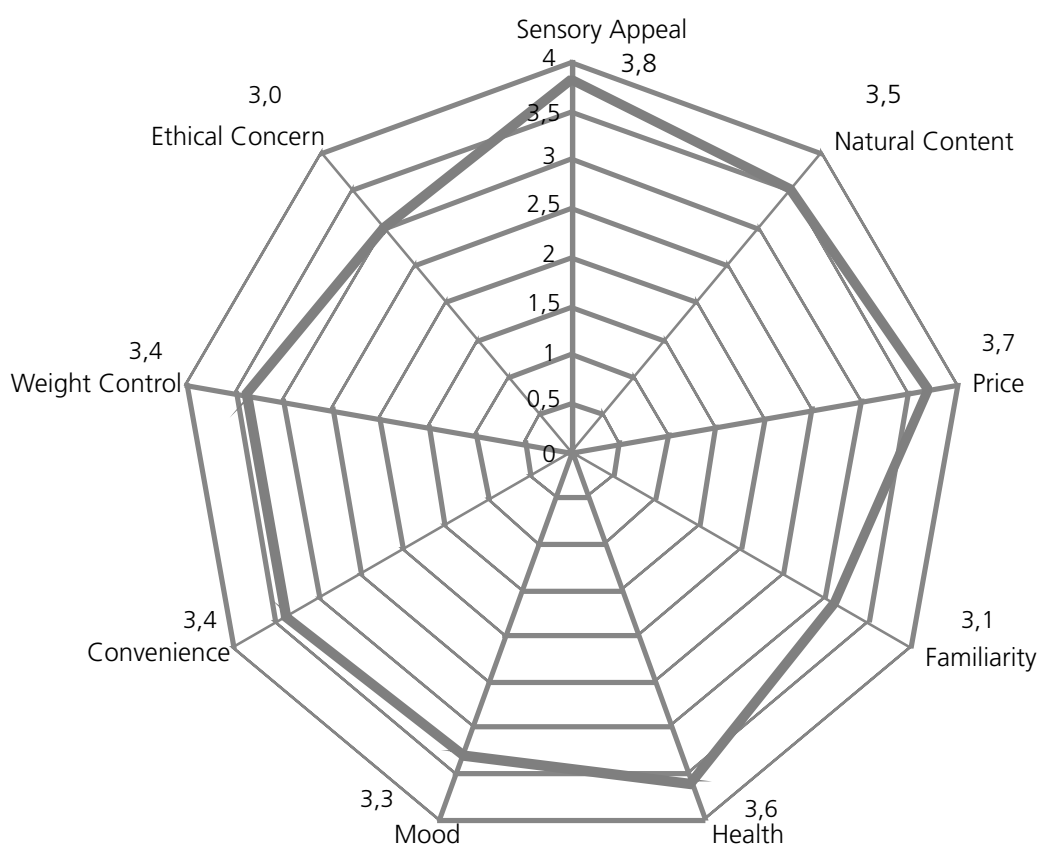

Figure 1. Relevance of the main determinants of eating behavior in the research participants. Teresina (PI), Brazil, 2019. 
health (3.6) standing out. The ethical concern aspect obtained the lowest score (3.0). Table 2 shows the expanded items of the FCQ with the average of the values attributed to each statement. Table 3 shows the main determinants of food choices according to gender and income.

Table 2. Relevance of the Food Choice Questionnaire items in the interviewed population. Teresina (PI), Brazil, 2019.

\begin{tabular}{|c|c|c|c|}
\hline Dimension & Items & Median & Standard deviation \\
\hline \multirow[t]{4}{*}{ Sensory Appeal } & Tastes good & 3.9 & 0.2 \\
\hline & Smells nice & 3.8 & 0.3 \\
\hline & Looks nice & 3.8 & 0.3 \\
\hline & Has a pleasant texture & 3.8 & 0.3 \\
\hline \multirow[t]{3}{*}{ Price } & Is good value for money & 3.8 & 0.4 \\
\hline & Is not expensive & 3.7 & 0.6 \\
\hline & Is cheap & 3.7 & 0.5 \\
\hline \multirow[t]{6}{*}{ Health } & Keeps me healthy & 3.9 & 0.3 \\
\hline & Is nutritious & 3.8 & 0.3 \\
\hline & Contains a lot of vitamins and minerals & 3.6 & 0.6 \\
\hline & Is good for my skin/teeth/hair/nails, etc. & 3.5 & 0.7 \\
\hline & Is high in protein & 3.4 & 0.7 \\
\hline & Is high in fiber and roughage & 3.5 & 0.7 \\
\hline \multirow[t]{3}{*}{ Natural Content } & Contains natural ingredients & 3.6 & 0.6 \\
\hline & Contains no additives & 3.4 & 0.7 \\
\hline & Contains no artificial ingredients & 3.4 & 0.7 \\
\hline \multirow[t]{3}{*}{ Weight Control } & Helps me control my weight & 3.5 & 0.7 \\
\hline & Is low in fat & 3.4 & 0.7 \\
\hline & Is low in calories & 3.3 & 0.8 \\
\hline \multirow[t]{5}{*}{ Convenience } & Can be bought in shops close to where I live or work & 3.5 & 0.7 \\
\hline & Is easily available in shops and supermarkets & 3.5 & 0.7 \\
\hline & Takes no time to prepare & 3.4 & 0.8 \\
\hline & Is easy to prepare & 3.3 & 0.8 \\
\hline & Can be cooked very simply & 3.3 & 0.9 \\
\hline \multirow[t]{6}{*}{ Mood } & Helps me cope with stress & 3.2 & 0.9 \\
\hline & Helps me to cope with life & 3.3 & 0.8 \\
\hline & Helps me relax & 3.3 & 0.8 \\
\hline & Keeps me awake/alert & 3.0 & 0.9 \\
\hline & Cheers me up & 3.3 & 0.8 \\
\hline & Makes me feel good & 3.7 & 0.5 \\
\hline \multirow[t]{3}{*}{ Familiarity } & Is what I usually eat & 3.3 & 0.8 \\
\hline & Is familiar. & 3.2 & 0.9 \\
\hline & Is like the food I ate when I was a child & 2.8 & 1.0 \\
\hline \multirow[t]{3}{*}{ Ethical Concern } & Is packaged in an environmentally friendly way & 3.5 & 0.7 \\
\hline & Has the country of origin clearly marked & 2.9 & 1.1 \\
\hline & Comes from countries I approve of politically & 2.7 & 1.1 \\
\hline
\end{tabular}

Table 3. Relevance for the main determinants of eating behavior in the research participants according to gender and income. Teresina (PI), Brazil, 2019.

\begin{tabular}{|c|c|c|c|c|c|c|c|c|c|c|c|c|}
\hline \multirow[b]{3}{*}{ Dimension } & \multirow{2}{*}{\multicolumn{2}{|c|}{$\begin{array}{l}\text { General } \\
(n=198)\end{array}$}} & \multirow{2}{*}{\multicolumn{2}{|c|}{$\begin{array}{c}\text { Male } \\
(n=149)\end{array}$}} & \multirow{2}{*}{\multicolumn{2}{|c|}{$\begin{array}{l}\text { Female } \\
(n=49)\end{array}$}} & \multirow{3}{*}{${ }^{*} p$} & \multicolumn{5}{|c|}{ Income ${ }^{\mathbf{b}}$} \\
\hline & & & & & & & & \multicolumn{2}{|c|}{$\begin{array}{l}<2 M^{c} \\
(n=106)\end{array}$} & \multicolumn{2}{|c|}{$\begin{array}{l}\geq 2 \mathrm{MW} \\
(\mathrm{n}=86)\end{array}$} & \multirow[t]{2}{*}{$p$} \\
\hline & Mean & $S D^{a}$ & Mean & SD & Mean & SD & & Mean & SD & Mean & SD & \\
\hline \multicolumn{13}{|l|}{ Food related } \\
\hline Sensory Appeal & 3.8 & 0.4 & 3.8 & 0.4 & 3.9 & 0.2 & 0.041 & 3.9 & 0.4 & 3.8 & 0.4 & 0.037 \\
\hline Natural Content & 3.5 & 0.7 & 3.5 & 0.7 & 3.5 & 0.7 & 0.647 & 3.4 & 0.7 & 3.5 & 0.6 & 0.366 \\
\hline
\end{tabular}


Table 3. Relevance for the main determinants of eating behavior in the research participants according to gender and income. Teresina (PI), Brazil, 2019.

2 of 2

\begin{tabular}{|c|c|c|c|c|c|c|c|c|c|c|c|c|}
\hline \multirow[b]{3}{*}{ Dimension } & \multirow{2}{*}{\multicolumn{2}{|c|}{$\begin{array}{l}\text { General } \\
(n=198)\end{array}$}} & \multirow{2}{*}{\multicolumn{2}{|c|}{$\begin{array}{c}\text { Male } \\
(n=149)\end{array}$}} & \multirow{2}{*}{\multicolumn{2}{|c|}{$\begin{array}{l}\text { Female } \\
(n=49)\end{array}$}} & \multirow{3}{*}{${ }^{*} p$} & \multicolumn{5}{|c|}{ Income $e^{\mathbf{b}}$} \\
\hline & & & & & & & & \multicolumn{2}{|c|}{$\begin{array}{l}<2 M^{c} \\
(n=106)\end{array}$} & \multicolumn{2}{|c|}{$\begin{array}{l}\geq 2 \mathrm{MW} \\
(\mathrm{n}=86)\end{array}$} & \multirow[t]{2}{*}{$p$} \\
\hline & Mean & $S D^{a}$ & Mean & SD & Mean & SD & & Mean & SD & Mean & SD & \\
\hline Price & 3.7 & 0.7 & 3.7 & 0.7 & 3.8 & 0.4 & 0.077 & 3.7 & 0.7 & 3.7 & 0.7 & 0.438 \\
\hline Familiarity & 3.1 & 0.9 & 3.2 & 0.9 & 3.0 & 1.0 & 0.659 & 3.0 & 0.9 & 3.2 & 0.8 & 0.263 \\
\hline \multicolumn{13}{|l|}{ Individual related } \\
\hline Health & 3.6 & 0.5 & 3.6 & 0.6 & 3.6 & 0.4 & 0.838 & 3.6 & 0.6 & 3.6 & 0.5 & 0.471 \\
\hline Humor & 3.3 & 0.7 & 3.3 & 0.8 & 3.2 & 0.7 & 0.450 & 3.3 & 0.7 & 3.3 & 0.8 & 0.406 \\
\hline Convenience & 3.4 & 0.8 & 3.3 & 0.8 & 3.5 & 0.8 & 0.154 & 3.5 & 0.8 & 3.1 & 0.9 & $<0.001$ \\
\hline Weight Control & 3.4 & 0.8 & 3.3 & 0.8 & 3.6 & 0.6 & 0.036 & 3.4 & 0.8 & 3.3 & 0.8 & 0.487 \\
\hline Ethical Concern & 3.0 & 0.9 & 3.1 & 0.9 & 3.0 & 0.9 & 0.471 & 2.9 & 0.9 & 3.2 & 0.9 & 0.010 \\
\hline
\end{tabular}

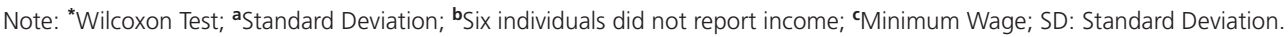

\section{ISCUSSION}

The results of this study showed that sensory appeal, price and health are the most relevant factors in the process of food selection in the sample studied. They also revealed that sensory appeal and weight loss are more important in females and that individuals with less purchasing power attach greater value to sensory appeal and convenience. Among the results found, minor importance attributed to the ethical issues stands out.

Food choice is a complex process and involves several factors, including the place where the meal takes place, since they can influence food choices, behavior and lifestyles. The autonomy for healthier food choices depends not only on the subject himself, but also on the environment in which he/she is inserted. In this connection, some settings that serve meals ready for consumption outside the home, may favor or hinder the incorporation of healthy food choices $[20,21]$. In view of the dietary globalization, a feeling of nostalgia arises in relation to the ways of eating, which motivates society to rescue traditional cuisine and to give value to the regional cuisine, in an attempt to enhance cultural roots [22].

The appreciation of the sensory appeal by the survey participants is probably due to the traditional gastronomy found in the public market, in which different regional dishes are prepared and marketed, characterized by high palatability, tradition and gastronomy that meets the preferences of these consumers who visit the market. In previous studies it was observed that the number of typical preparations consumed individually in each meal varied from one to three options of dishes. The typical preparations that are part of the menus included predominantly those made with beef, pork and lamb with sauce, offal, guts and poultry [23].

An interesting finding is that each meal taken outside the home adds an average of 134 calories compared to the same meal consumed at home and can result in a gain of up to two pounds $(0.9 \mathrm{~kg})$ per year if having such meal once a week [24]. Thus, Food Guidelines (FG) can be used to guide the community as to the adoption of a healthy diet, especially when the meal is eaten outside the home, being an instrument that induces public policies aimed at promoting, supporting and protecting health of the population $[25,26]$. 
The FG for the Brazilian population admits that, although people have great responsibility for food choices, the adoption of recommendations is far from being a mere individual decision, requiring public policies and regulatory actions by the Government to make the environment more conducive to the practice of healthy eating, reducing NCDs and ensuring food and nutritional security $[26,27]$. In settings such as public markets, the typical character of the preparations served in food outlets can encourage the consumption of meals [5]. However there are other factors that motivate food choices that deserve investigation.

In the market studied, sensory appeal was described in all categories assessed as the most relevant factor in the food choice process. Taste is one of the least negotiable determinants within the food context, being the main factor for the pleasure of eating [7]. Possibly, the consumption of meals in this space is motivated by the offer of typical meals and by the characteristic flavor of the preparations.

In relation to price, the second most determining factor in food choice, it was observed that more than half of the interviewees had a low income, which may explain the importance attributed to this factor. Food purchase has the greatest weight in the budget of the poorest families, and is especially sensitive to the variation in the price of food products [28].

The appreciation of sensory appeal and price are obstacles to the choice of a healthy diet [24]. In this connection, the importance of health professionals for the development of public policies for the improvement quality of food served in restaurants stands out, encouraging small changes like preparation of steamed, roasted or grilled food instead of fried food and the use of fresh ingredients, without affecting the taste and cost of the meal served [24]. In addition, the predominance of men in the sample assessed may justify the greater importance attributed to sensory appeal and price, since this group gives less value to health [29].

The results of this study are in line with research conducted in the United Kingdom and the United States, in which the most valued dimension was also the sensory appeal. The price and health dimensions were also considered of top importance; what varied was the degree of importance attributed to those dimensions according to the population in question $[14,30]$.

Ina cross-cultural study carried out in New Zealand, Japan, Malaysia and Taiwan, the only country that fully coincided with the results of this investigation was New Zealand, with sensory appeal, price and health respectively being the most valued attributes. These data show the variations that exist between different countries which suggests that these data may be influenced by the cultural differences that exist between nations [31].

As for food choice, one prominent fact observed in the differences found between men and women, was that women gave more importance to sensory appeal and weight control. The relationship between body image and the female gender has already been well established in the literature; it is even considered as a standard discomfort because dissatisfaction among women is the norm [32].

Another study that compared the reason for food choices according to gender in Americans and Chinese individuals, reported that there was no difference regarding the sensory appeal dimension. However there was a difference in relation to weight control in the female group; just like in our investigation, women give greater importance to this dimension [33].

When the determinants of food choice were compared with income, the differences observed were in relation to sensory appeal, convenience and ethical concern. The socioeconomic determinants related to the individual play a central role in the motivations and food choices, being able to restrict, unbalance and interfere in the priorities related to the food choice process [7]. 
An alarming aspect is that the ethical concern received the lowest scores in all the categories evaluated. This finding coincides with a review study that evaluated the application of FCQ in several countries and showed that ethical concern is not an important issue and is not taken into account when people choose their food [34].

The lack of commitment with environmental issues favors uncontrolled consumption and promotes impacts on the environment, which have a direct impact on the health of the population [35]. Thus, a large work of environmental awareness by public health professionals is necessary to obtain an attitude change both in the development of activities and in aspects of life, individuals and society in relation to the environment [36].

The Brazilian FG not only does not recommend the consumption of ultra-processed foods, because of potential damage to health but also acknowledges the impacts that these products cause to the environment, as it takes into account the high production of waste with the disposal of packaging, the stimulus to monocultures, excessive use of pesticides and water, the high expenditure of energy and pollution generated during transportation, being a reference for health professionals and an awareness tool [20].

There is a certain recognition that in order to foster environmental sustainability it is necessary to include the participation of local populations in activities that value and preserve nature, such as encouraging the creation of vegetable gardens and small farms, and reflecting on the way people live and work [35]. In this connection, the importance of the role played by public health professionals, who facilitate the understanding of the relationship between the practice of healthy eating and environmental sustainability, is highlighted [35,37].

From these interpretations, the complex interactions involving food choice were perceived $[12,38]$. The results of this study provide important information that allows the identification of social variables that may influence the decision to purchase food and the food choice.

Some limitations on the results of this study deserve consideration, noting that the FCQ did not assess the influence of advertisements, beliefs and religiosity in order to allow a deeper understanding of food choices [13]. It is important to add that the attributes highlighted here by the diners cannot be considered as strictly adequate or not in food choice given the complexity of cultural, social and psychobiological factors that influence dietary intake.

Another limiting aspect of the study concerns the fact that this study was conducted in just one public market. Thus, the results found here cannot be generalized or extrapolated to other realities, since culture and regionalism interfere in the food selection process. In addition to the cross-sectional design, the study highlights the main determinants of food choice at the time of data collection, which can change with time and circumstances.

Despite these limitations, it is believed that the results of this study provide important information about the local reality, which can contribute to the adoption of public food policies that meet the needs of individuals and provide encouragement to seeking healthy environments and healthy eating. Another positive aspect that ought to be mentioned is the fact that this investigation yielded pioneer findings.

\section{CONCLUSION}

The investigation shows that sensory appeal was the main determinant of food consumption in public market restaurants. Other factors, such as price and health, also showed significant 
importance in food choice. It became evident that the ethical concern, being directly related to the sustainability of the food system, has not yet been incorporated by the public studied, as the lack of environmental control directly impacts people's health and the price of food, both issues pointed out as important by that population. Women understand that weight loss is based on food while individuals with lower income incorporate the convenience factor for the selection of food. Thus, such aspects must be taken into consideration for the development of public policy strategies and tools that include collective eating and environmental education.

\section{CONTRIBUTORS}

The author ACC MOURA participated in the conception, design and data analysis of this manuscript. The authors MTSM MELO, BLS SILVA, and SMRS PAZ participated in the analysis and interpretation of data. The review and approval of the final version were carried out by the authors AA PAIVA and CMRG CARVALHO.

\section{REFERE N CES}

1. World Health Organization. Global strategy on diet, physical activity and health. Geneva: Organization; 2004 [cited 2020 Jan 20]. Available from: https://www.who.int/dietphysicalactivity/strategy/eb11344/strategy_ english_web.pdf

2. Queiroz PWV, Coelho AB. Alimentação fora de casa: uma investigação sobre os determinantes da decisão de consumo dos domicílios brasileiros. Rev Anál Econ. 2017;35(67):67-104.

3. Instituto Brasileiro de Geografia e Estatística. Pesquisa de orçamentos familiares 2017-2018: primeiros resultados. Rio de Janeiro: Instituto; 2019.

4. Ferreira C, Marques T, Guerra P. Feiras e mercados no Porto: velhos e novos formatos de atividade econômica e animação urbana. Rev Geo Ord Terr. 2015;8:75-102. https://doi.org/10.17127/got/2015.8.005

5. Andrade L. Os mercados e os dilemas da autenticidade. uma análise do mercado central de Belo Horizonte. Interseções: Rev Est Inter. 2017;19(2):443-62. https://doi.org/10.12957/irei.2017.32020

6. Carvalho CA, Fônseca PCA, Nobre LC, Priore SE, Franceschini SCC. Metodologias de identificação de padrões alimentares a posteriori em crianças brasileiras: revisão sistemática. Cienc Saúde Colet. 2016;21:143-54. https://doi.org/10.1590/1413-81232015211.18962014

7. Moraes JMM. Por que as pessoas comem o que comem? Comparação das motivações para comer entre dois contextos socioeconômicos díspares no Brasil [tese]. São Paulo: Universidade de São Paulo; 2017.

8. Hamilton J, Mcllveen H, Strugnell, C. Educating young consumers: a food choice model. J Consum Stud Home Econ. 2000;24:113-23. https://doi.org/10.1046/j.1365-2737.2000.00151.x

9. Cardoso S, Santos O, Nunes C, Loureiro I. Escolhas e hábitos alimentares em adolescentes: associação com padrões alimentares do agregado familiar. Rev Port Saúde Pública. 2015;33(2):128-36. https://doi.org 10.1026/j.rpsp.2024.07.00410

10. Koritar P. Atitudes em relação à saúde e sabor dos alimentos e imagem corporal entre mulheres [tese]. São Paulo: Universidade de São Paulo; 2013.

11. Dover RVH, Lambert EV. "Choice Set" for health behavior in choice-constrained settings to frame research and inform policy: examples of food consumption, obesity and food security. Int J Equit Health. 2016;15(1):48. https://doi.org/10.1186/512939-016-0336-6.

12. Cardozo DR, Ferrante VLSB, Almeida LMDMC, Paschoalino A. Hábitos alimentares: desvendando padrões e escolhas sociais. Rinte. 2018;4(1).

13. Prefeitura Municipal (Teresina). Superitendência de Desenvolvimeno Urbano Sul. Histórico dos mercados públicos da zona sul de Teresina. Teresina: Prefeitura; 2016.

14. Steptoe A, Pollard TM, Wardle J. Development of a measure of the motives underlying the selection of food: the food choice questionnaire. Appetite.1995;25(3):267-84. 
15. Heitor SFD, Estima CCP, Neves FJ, Aguiar LS, Castro SS, Ferreira JES. Tradução e adaptação cultural do questionário sobre motivo das escolhas alimentares (Food Choice Questionnaire-FCQ) para a língua portuguesa. Ciênc Saúde Coletiva. 2015;20(1):2339-46. https://doi.org/10.1590/1413-81232015208.15842014

16. Heitor SFD, Ferreira JES, Castro SS. Validade da estrutura fatorial da escala de versão brasileira do Food Choice Questionnaire. Ciênc Saúde Coletiva. 2018 [citado 30 mar 2019]. Disponível em: http://www. cienciaesaudecoletiva.com.br/artigos/validade-da-estrutura-fatorial-da-escala-de-versao-brasileira-do-foodchoicequestionnaire/16614?

17. StataCorp. Stata Statistical Software. Relalease 12 [software]. College Station: StataCorp; 2011.

18. Badziak RPF, Moura VEV. Determinantes sociais da saúde: um conceito para efetivação do direito à saúde. $R$ Saúde Pública. 2010;(3)1:69-79.

19. Jomori MK, Proença RPC, Calvo MCM. Determinantes de escolha alimentar. Rev Nutr. 2008;21(1):63-73. https://doi.org/10.1590/S1415-52732008000100007

20. Ministério da Saúde (Brasil). Guia alimentar para a população brasileira. 2a. ed. Brasília: Ministério; 2014.

21. Bezerra IN, Curioni C, Sichieri R. Association between eating out of home and body weight. Rev Nutr. 2012;70(2):65-79. https://doi.org/10.1111/j.1753-4887.2011.00459.x

22. Silva Julião MS, Andrade FJF, Neto LG. Ensaio sobre a identidade cultural cearense a partir do "Baião de Dois". Púb Priv. 2018;16(32):67-88.

23. Melo MTSM, Moura ACC, Silva BLS, Santos MDC, Paz SMRS, Santos MM. Nutritional characterization of the typical food menu offered in the public market and its reflection on health. J. Culin Sci Technol. 2020:1-11. https://doi.org/10.1080/15428052.2020.1733162

24. Newson RS, Maas RV, Beijersbergen A, Carlson L, Rosenbloom C. International consumer insights into the desires and barriers of diners in chossing healthy restaurant meals. Food Quali Prefer. 2015;43:63-70. https:// doi.org/10.1016/j.foodqual.2015.02.016

25. Bortolini GA, Moura ALP, Lima AMC, Moreira HOM, Medeiros O, Diefenthaler ICM, et al. Guias alimentares: estratégia para redução do consumo de alimentos ultraprocessados e prevenção da obesidade. Rev Panam Salud Publica. 2019;43(59). https://doi.org/10.26633/RPSP.2019.59

26. Pinheiro MC, Moura ALSP, Bortolini GA, Coutinho JG, Rahal LS, Bandeira LM, et al. Abordagem intersetorial para prevenção e controle da obesidade: a experiência brasileira de 2014 a 2018. Rev Panam Salud Publica. 2019;43(58). https://doi.org/10.26633/RPSP.2019.58

27. Louzada MLC, Canella DS, Jaime PC, Monteiro CA. Alimentação e saúde: a fundamentação científica do guia alimentar para população brasileira. São Paulo: Faculdade de Saúde Pública da Universidade de São Paulo; 2019.

28. Claro RM, Maia EG, Costa BVL, Diniz DP. Preço dos alimentos no Brasil: prefira preparações culinárias a alimentos ultraprocessados. Cad Saúde Pública. 2016;32(1):e00104715. https://doi.org/10.1590/0102$311 \times 00104715$

29. Oliveira MM, Daher DV, Silva JLL, Araújo ASSC. A saúde do homem em questão: busca por atendimento na atenção básica de saúde. Ciênc Saúde Coletiva. 2015;20(1):273-8. https://doi.org/10.1590/1413-8123 2014201.21732013

30. Glanz K, Basil M, Maibach E, Goldberg J, Snyder D. Why Americans eat what they do: taste, nutrition, cost, convenience, and weight control concerns as influences on food consumption. J Am Diet Assoc. 1998;98(10):1118-26.

31. Prescott J, Neill OL, Yau NJN, Steven R. Motives for food choice: a comparison of consumers from Japan, Taiwan, Malaysia and New Zealand. Food Qual Prefer. 2002;13(7-8):489-95. https://doi.org/10.1016/s09503293(02)00010-1

32. Costa ACP, Torre MCMD, Alvarenga MS. Atitudes em relação ao exercício e insatisfação com a imagem corporal de frequentadores de academia. Rev Bras Educ Fís Esporte. 2015;29(3):453-64. https://doi.org/10. 1590/1807-55092015000300453

33. Pearcey SM, Zhan GQ. A comparative study of American and Chinese college students' motives for food choice. Appetite. 2018;123(1):325-33. https://doi.org/10.1016/j.appet.2018.01.011

34. Cunha LM, Cabral D, Moura AP, Almeida MDV. Application of the Food Choice Questionnaire across cultures: systematic review of cross-culturaland single country studies. Food Qual Prefer. 2018;64(1):21-36. https:// doi.org/10.1016/j.foodqual.2017.10.007 
35. Bruno VHT, Habiomorad PHL, Catarucci FM, Carvalhaes MABL, Patrício KP. Conexão com a natureza e associação com motivos de escolhas alimentares em profissionais da atenção primária à saúde. Ciênc Saúde Coletiva. 2019[citado 4 dez 2019];25(Suppl2). Disponível em: http://www.cienciaesaudecoletiva.com.br/ artigos/conexao-com-a-natureza-e-associacao-com-motivos-de-escolhas-alimentares-em-profissionais-daatencao-primaria-a-saude/17282

36. Zannata P. Gestão ambiental e o desenvolvimento sustentável. Rev Ges Sust Ambient. 2017;6(3);296-312. https:doi.org/10.19177/rgsa.v6e32017296-312

37. Ribeiro H, Jaime PC, Ventura D. Alimentação e sustentabilidade. Est Avan. 2017;31(89):185-98. https://doi. org/10.159/s013-40142017.31890016

38. Klotz-Silva J, Prado SD, Seixas CM. Comportamento alimentar no campo da Alimentação e Nutrição: do que estamos falando? Physis. 2016;26(1):1103-23. https://doi.org/10.1590/S0103-73312016000400003 